\title{
Política Científica e Sociedade do Conhecimento
}

Há um forte movimento da sociedade brasileira nas duas últimas décadas, no sentido de prover-se dos meios ideais para participar, mais competitivamente no cenário político e econômico global. Isso implica em uma abertura mental para a recepção e aceitação de novos parâmetros de fazer ciência e de produzir conhecimento. Em vários campos tradicionais do saber profissional-científico tem havido uma revitalização teórica e uma diversificação das metodologias e procedimentos de pesquisa. Campos de saber mais novos têm buscado as condições adequadas, em termos de apoio material e intelectual, para a produção da explicação de fatos naturais e para a formulação de compreensão a respeito dos fenômenos humanos e sociais.

Nesse sentido, tem havido um crescimento consistente, em qualidade e quantidade, dos programas de pós-graduação e uma conseqüente consolidação dos espaços de produção dos conteúdos para o diálogo científico, bem como da comunicação da ciência. Tudo isso, de outro lado, está associado à abertura política e ao sentimento de liberdades individuais e coletivas que o país e, assim, sua população passou a ter, acanhadamente, após a superação do período de ditadura militar que todos os brasileiros sofreram de 1964 até o início do Governo do Sr. Sarney e, mais descontraidamente, após o estabelecimento em 1988, da "Constituição cidadã".

A partir de então, o país tem se permitido a trabalhar para alcançar um lugar ideal no mundo da economia global, que vá além da exportação de bens primários e da importação de mercadorias para consumo pessoal ostentatório. Vem sendo muito difícil para a população, como um todo, vencer, principalmente, o sentimento de colonizado ou de oprimido, para lembrar de uma sociedade terceiro-mundista descrita por Paulo Freire em suas reflexões sobre uma pedagogia que possa levar uma população a superar o analfabetismo e a miséria imposta pelos colonizadores e seus êmulos em países como o Brasil.

Então, para além da superação do medo imposto pelo "cala boca" da ditadura militar no período acima mencionado, que depende de uma educação capaz de elevar a escolarização média do brasileiro para mais do que seus atuais seis anos, precisa-se de uma superação das restrições mentais, permitindo que a produção de conhecimento se estabeleça como uma base de ações e de reflexões em torno da construção científica eficaz. A mais que isso, que se produza como resultado horizontes ou cenários de futuro que não sejam apenas idealizações sem conseqüências ou meros exercícios de estratégia ou refinamento de técnicas de planejamento. 
Tudo isso, nestes últimos anos, em nível global, como numa moldura, configura-se por uma denominada sociedade do conhecimento, de conteúdo político ambíguo, de intenção econômica clara e de conseqüências humanas devastadoras pelo acento e produção de exclusões várias. Acentuam-se exclusões como as do direito de ter um emprego dignamente remunerado, de contar com garantias previdenciárias, de poder sindicalizar-se e defender adequadamente direitos, etc. Produzem-se exclusões como a de ter pleno acesso a toda a informação, de ser alfabetizado digitalmente, de poder ir e vir livremente sem temer ser preso injustamente ou morto inesperadamente, etc.

É para tais fenômenos, sobretudo, humanos e sociais que são necessárias decisões voltadas ao estabelecimento de políticas científicas e, especialmente, para as ações que levam à sua plena execução. Isto implica políticas de estado, legalmente instituídas nos parlamentos com a ampla participação e discussão pela sociedade, em última instância, a financiadora de todas as iniciativas de ampliação do conhecimento.

Para isso, talvez somente para isso e por isso, justifica-se a realização de eventos que reúnem cientistas e estudiosos como foi o VI ENANCIB, promovido pela Associação Nacional de Pesquisa e Pós-Graduação em Ciência da Informação [ANCIB] e realizado pelo Programa de Pós-Graduação em Ciência da Informação da Universidade Federal de Santa Catarina [PGCIN/UFSC], de onde provém o material que compõe esta Edição monográfica especial de Encontros Bibli.

Este número - VI ENANCIB: melhores trabalhos - traz os quatorze textos apontados pelas Coordenações dos Grupos de Trabalho da ANCIB, como os melhores, dentre os aprovados e apresentados durante o evento. De cada Grupo foram selecionados dois trabalhos e são estes que ora Encontros Bibli traz para os seus leitores.

A todos e a todas, deseja-se uma boa leitura e espera-se que esta edição represente um bom aporte conceitual e teórico para os próximos trabalhos de cada um[a].

Prof. Francisco das Chagas de Souza - Editor

chagas@cin.ufsc.br ou bibli@,cin.ufsc.br

Departamento de Ciência da Informação

Programa de Pós-Graduação em Ciência da Informação

Universidade Federal de Santa Catarina - Brasil

Florianópolis, Ilha de Santa Catarina, março de 2006. 